\title{
Research on the Pricing Formula on Small Loan for RCC in China
}

\author{
Aiwen Yang \\ Information Engineering School, Hangzhou Dianzi University. \\ Hangzhou, Zhejiang, China 310028 \\ yaw812@163.com
}

\begin{abstract}
In order to price the small loans for RCC, this paper studies the existing commercial bank lending rates and interest rate pricing, and then proposes two pricing formulas about small loans for Chinese RCC. One is applied to price the basic interest rate of small loan, and the other is applied to price the interest rate for specific customer's loans. Combined with the status of the RCC in Xiangshan County, the paper points out that the two formulas different application scenarios.
\end{abstract}

Keywords-Rural Credit Cooperatives (RCC); small loans; interest rate pricing; lending rate

\section{INTRODUCTION}

From the practice of domestic and foreign, microfinance can be divided into two kinds, one is welfarism microfinance (or called pro-poor microfinance), and the other is institutionalism microfinance (or called small commercial microfinance). This paper analysis the interest rate pricing about commercial microfinance.

The People's Bank of China (PBOC) canceled the financial institutions of RMB loans' interest rate caps in 2004 , but still controls the RCC's interest-rate ceiling. It is prescribed that the interest rate can not exceed 2.3 times of the benchmark lending rate. Combined with interest rate floor on the loans, that RCCs' loan interest rate is [0.9, 2.3] times of the People's Bank benchmark rate. How to determine the level of interest rates on small loans, for the increasingly competitive market environment, has great significance. On the one hand, the liberalization of interest rates puts forward higher requirements for the RCC to price interest rates and control risk. On the other hand, this provides an important development opportunity for RCC. This is significant for the RCC to study various interest rates pricing on loans.

\section{ANALYSIS OF BANK LOAN PRICING MODEL}

The lending rates should at least cover the cost of capital, management costs and risk costs. Management costs include accepting the application, surveying the project before loaning, loaning, recovering loans, inspecting loan, as well as dealing with the aftermath of bad debts. The cost representing the ratio of the loan amount is much higher than the payment of a large loans cost ratio. So commercial bank loans will have the tendency to focus on large loans. Risk costs of small loans may be more stability because of slight projects and diversified customers even if the economy is in a period of heightened volatility. But it is difficulty for customers who apply for small loans to withstand natural disasters and market risks. Therefore, the interest rates on small loans based on sustainable development which the RCC offered should be higher than the same period of high lending rates of commercial banks.

The pricing models on loan include cost-plus pricing model, price leadership pricing model, customer profitability analysis of pricing models and cost-benefit pricing. For pricing small loans, there are the Morduch breakeven law and Rosenberg model. This paper argues that cost-plus pricing model, price leadership pricing model, Morduch breakeven law and Rosenberg models, they are significant, these theories will be described in detail hereinafter.

\section{A. The Cost-plus Pricing Model}

The model assumes that any lending rates should include the following four components: capital cost, loan fees, risk compensation and target revenue. The cost of capital is the bank loan funds to raise the costs incurred, mainly the cost of raising funds. Loan fees, also known as "non-funding of operating costs," are composed by credit checks on borrowers, the fees paid by credit analysis, collateral identification, appraisal fees, credit information document fee, special apparatus and equipment depreciation costs. Default risk and term risk constitute a major part of risk compensation. The target income is that the bank provides a return on capital required level of profits for Shareholders of the bank. The advantage of this model is to ensure that banks make profits and banks can know all costs of the loans, in order to ensure that the profit levels achieved. And the disadvantage is that banks price the loan from their own point of view, ignoring the customer demand, competition, changes in market interest rates, comprehensive customer contributions and other factors, it is possible that the bank loses market because of overpricing.

\section{B. Price Leadership Pricing Model}

The pricing methods is widely used by international bank, also is known as base rate plus point model. The price leadership pricing model determines a benchmark interest rate $(I)$ as a "basic price" and then determines the different levels of risk premium $(R)$ for credit rating or risk for different levels of customers, the reference effective interest rate on the loan is equal to the reference interest rate plus the risk premium

$$
P=I+R
$$

The model is more targeted, flexible and competitive. Professionals can broke down loan business, and work out a loan closer to the market price. The disadvantage is that 
cost factors of bank loans have not been considered. If the total cost of capital costs and operating costs is more than the benchmark interest rate, the bank will not get enough return or even a loss. In addition, customer's comprehensive financial contribution has not been considered, so the pricing model is not comprehensive enough.

\section{Murdoch Breakeven Law}

This model can be used to estimate interest rates which the different types of microfinance institutions want to achieve breakeven and commercialization of sustainable development goals. Murdoch suggests the interest rates for MFIs balancing profit and loss under the condition that fund cost should not be taken into consideration, i.e., capital completely comes from free supply like donations. MFI interest rates to achieve breakeven conditions is following

$$
r=\frac{c+a-i}{1-a}
$$

The " $a$ " is the loan delinquency rate, the " $c$ " is the cost of every dollar loans excluding the cost of capital, and the " $i$ " is net investment income of the loans.

\section{Rosenberg Model}

Just like Murdoch and his Murdoch Breakeven Law, Richard Rosenberg presents other model for MFI to measure interest rates for sustainable development. The effective interest $\operatorname{rate}(R)$ is the function of five variables which is the lending level administrative cost $\operatorname{ratio}(A E)$, loan loss rate $(L L)$, the cost of capital rate $(C F)$, expected profitability $(K)$ and return on investment $(I I)$.The formula is following:

$$
R=\frac{K+A E+L L+C F-I I}{1-L L}
$$

The calculation methods of $A E 、 L L 、 C F 、 K 、 I I$ is the ratio that administrative costs, loan loss amount, capital costs, expected profits and investment income compares with the average loan.

\section{THE PRICING FORMULA ON SMALL LOAN FOR THE $\mathrm{RCC}$}

\section{A. Private Lending Interest Rate and the PBOC's Benchmark Interest rate}

In the above models, there is one major problem that the model does not consider the market interest rate pricing for other organizations, such as the price of interest rates of non-formal financial markets or the private financial market. Generally, private lending rate for rural financial institutions have a very important guiding significance meaning that it can reflect the supply and demand of funds truly. From the Fig. 1, private lending rate and the PBOC's benchmark interest rate are virtually the same trend.

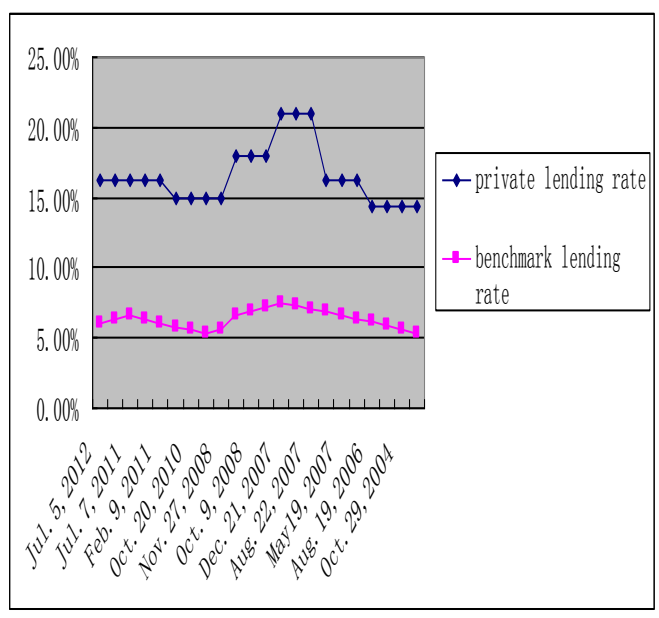

Figure 1. Data sources: private lending rate is from lender's estimate, the PBOC's benchmark interest rate is from http://www.sina.com.cn

In the Fig. 1, we can see that private lending rates almost can truly reflect the real money supply and demand. In general, private lending rate will not fall below $12 \%$ per annum, which will not fall down $1 \%$ per month. The upper limit is generally not more than $2.5 \%$ per month (if more than $2.5 \%$ per month in the event of civil disputes, the court should characterize this case as usury, and this is not conducive to the lender of funds). Due to the relatively ample supply of funds, private lending rates play guiding role on interest rate cap in this price for rural financial institutions. The interest rate cap of financial institutions can not exceed the private lending rate. Or not there will be "substitution effect", and rural financial institutions will lose VIP customers.

This paper combines the above several models those are suitable for small loans of RCC and proposes the pricing models.

\section{B. How to Price the Basic Lending Rate on Small Loans for the Target RCC}

Assuming $R_{p}$ the private lending rate, $R_{f}$ the interest rate on small loans of $\mathrm{RCC}$, then there is $R_{f} \leq R_{p}$. In the current rural financial markets, the RCC is still in relative monopoly position, so the cost plus method and the price leadership pricing model have a certain moderation and operability, but these methods must be improved in order to overcome the drawbacks. Model is as follows:

$$
R_{f}= \begin{cases}R_{f}=R_{p} & \text { if } R_{p} \leq C_{1}+C_{2}+R_{1}+R_{2} \\ R_{f}=C_{1}+C_{2}+R_{1}+R_{2} & \text { if } R_{P}>C_{1}+C_{2}+R_{1}+R_{2}\end{cases}
$$

In Equation 4, $C_{1}$ is the cost of capital, $C_{2}$ is the cost of capital for loan fees, $R_{1}$ is risk compensation, and 
$R_{2}$ is target revenue. As for the management of interest rates cap and floor on small loans still exist, the RCC must consider the private lending $\operatorname{rate}\left(R_{p}\right)$ when they price small loans, if the private lending rates $\left(R_{p}\right)$ less than or equal the total of the cost of capital $\left(C_{1}\right)$, loan fees $\left(C_{2}\right)$, risk compensation $\left(R_{1}\right)$ and the target revenue $\left(R_{2}\right)$, the RCC must reduce the target revenue( $\left.R_{2}\right)$ and do other improvements and adjustments. When the private lending rate $\left(R_{p}\right)$ is greater than the total of the cost of capital $\left(C_{1}\right)$, loan fees $\left(C_{2}\right)$, risk compensation $\left(R_{1}\right)$ and the target revenue $\left(R_{2}\right)$, the RCC's basic interest rate on small loans can be determined as the total of the cost of capital $\left(C_{1}\right)$, loan fees $\left(C_{2}\right)$, risk compensation $\left(R_{1}\right)$ and the target gain $\left(R_{2}\right)$, and this pricing has advantage over private lending rate. Of course, $R_{f}$ must be in the range of interest rate collar $[0.9,2.3]$ times of the PBOC's benchmark rate.

\section{How to Price the Small Loan Rate for Different Customers}

If the RCC has gotten the basic interest rate on small loans by using the formula (4), then the next work is that how to price lending rates for different customers. For each specific customer, the resulting pricing model on small loan is following:

$$
R=R_{f} \pm A \times 10 \% \times R_{f}
$$

$A \times 10 \% \times R_{f}$ is similar to a hike rate, $A$ is equal to a constant $0,1,2,3,4$ etc. For different credit rating of customers, the RCC can price the different lending rate by using formula (5). If the applicant's credit conditions meets the RCC's credit system conditions about basic interest rate, given basic small loans rate $\left(R_{f}\right)$. If the applicant whose credit condition is worse than the RCC's credit system conditions, the RCC can press $R_{f} \times 10 \%$ to increase up in multiples. If the applicant whose credit condition is better than RCC's credit system conditions, the RCC can press $R_{f} \times 10 \%$ to cut back in multiples. Of course, the formula (5) must be in the range of interest rate collar [0.9, 2.3] times of the PBOC's benchmark rate.

\section{APPlication OF THE TwO MODELS}

\section{A. How to Use Equation (4) and Price basic Interest Rates on Small Loans}

Based on our investigation and statistics about the RCC in Xiangshan County in 2012, capital cost is about $4.96 \%$, loan fees rate is about $2.20 \%$, risk compensation rate is about $1.12 \%$, and the target rate of return is $5.22 \%$. Then the RCC can price the interest rates on small loan $13.5 \%$. The price is more than the lowest rate of private lending rate, and lower than the lending rate in most cases. In general, private lending rates will not fall below $1 \%$ per month, which without considering the time value of the case; and $12 \%$ per annum. The majority of private lending rates are $16 \%$, so the price $13.5 \%$ has an advantage. Meanwhile, the price must be in the range of interest rate collar $[0.9,2.3]$ times of the PBOC's benchmark rate, and then the RCC can price interest rate on small loan $13.5 \%$.

\section{B. How to Price Different Interest Rates for Different Customers}

Faced with specific customers, the RCC can apply the formula (5) to price the applicant's interest rates on small loan. In general, the banks should follow the "high-risk, high-yield" when they loans, and follow the "5C principle, 5P principle, CAMEL principles" in providing credit to customers.

When pricing the small loans, RCC should also consider the following factors: the loan amount, time, purpose, source of repayment of loan and guarantees. If some customer meets the basic rate credit conditions, the RCC will give him the basic interest rate of micro-loans $\left(R_{f}\right)$. If some customer has high-quality credit, the rate will be float downward. If his credit condition is slightly worse than the credit condition about basic interest rate, then the rate will float up. It is very important to develop rural social credit system and foster the concept of credit for the development of rural financial institutions, and provide an important platform. The Government of Xiangshan County, Zhejiang Province launched rural credit project construction activities to help establish a "credit township (town) and village households" to carry out micro-credit. It is necessary provide a basis for the risk-based pricing that the People's Bank of China established credit information system improved customer base databases and implement SME credit rating system.

In the specific operation, if the customer Joan applies for a small loan, firstly the loan officer reviews the case of Joan's credit condition. If Joan meets the credit conditions about basic interest rate, the RCC will give her the basic interest rate of micro-loans $\left(R_{f}\right)$. If the town and village where Joan lives is "credit town, credit village", the lending rate offered will preferential and will be $R_{f}-R_{f} \times 10 \%$. If she also participates in guaranteed loans, the lending rate offered will be $R_{f}-R_{f} \times 20 \%$, If Joan has the collateral, the lending rate offered will be $R_{f}-R_{f} \times 30 \%$. But if Joan can not fully meet the credit requirements, the interest rates on small loan offered will be $R_{f}+R_{f} \times 10 \%$ or higher.

\section{REFERENCES}

[1] Yu Zhang. Rural credit cooperatives Pricing Analysis [J] Commercial Times .2010 (8) $66 \sim 67$.

[2] Ying Qian Wang, Qing Wang, Yi Liuyi. The trend of interest rate market commercial bank loan pricing $[\mathrm{J}]$ Commercial Bank Management .2010 (2) 36 37.

[3] Xianjun Fang, Quanli Li, Yanqing Ge.Commercial bank microcredit interest rate pricing research $[\mathrm{J}]$. Times Financial.2008 (5) $66 \sim 67$. 
[4] Morduch, J., 1997 Micro finance Sustainability: A Consistence Framework and New Evidence on the Grameen Bank.Discussion Paper from Department of Economies and HIID, Harvavd University.

[5] Richard, Rosenberg.2002.Micro credit Interest Rates.CGAP Ossional Paper, No.1, World Bank.

[6] Jiajing Lu. Microcredit interest rate pricing theory and practice of the Postal Savings Bank [J]. Banker.2009 (2) 47 48. 